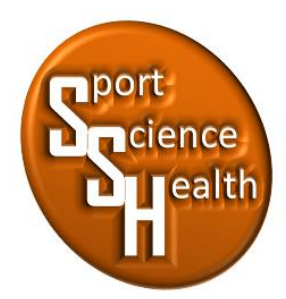

ISSN 2715-3886

\title{
Studi Tentang Indeks Massa Tubuh Terhadap Kondisi Fisik Atlet Sepakbola Akademi Arema Ngunut Tulungagung
}

\author{
Riki Santoso ${ }^{1 *}$ \\ ${ }^{1}$ Jurusan Pendidikan Jasmani, Kesehatan dan Rekreasi, Fakultas IImu Keolahragaan, \\ Universitas Negeri Malang, Jalan Semarang No 5, Malang, Jawa Timur, 65145, Indonesia \\ *Penulis koresponden: santosoricky67@gmail.com, 081359793325
}

Artikel diterima: 2 Januari 2020; direvisi: 23 Januari 2021; disetujui: 26 Januari 2021

\begin{abstract}
This study aims to determine body mass index, and the relationship between body mass index and physical condition. Using a quantitative descriptive design with a correlational method. The research subjects wer e 17 athletes. Results: (1) The athlete's body mass index was $76.47 \%$. (2) body mass index and velocity (0.418). (3) body mass index and abdominal muscle strength (0.075). (3) body mass index and agility (0.493). (4) bodymass index and endurance (0.289). (5) between body mass index and explosive power (0.438). Conclusion: (1) the athlete's body mass index is in good condition, (2) the only significant relationship is bodymass index with agility, others are not significant.
\end{abstract}

Keyword: body mass index, physical condition, football athletes

\begin{abstract}
Abstrak: Penelitian ini bertujuan mengetahui indeks massa tubuh, dan hubungan antara indeks massa tubuh dengan kondisi fisik. Mengunakan rancangan deskriptif kuantitatif dengan metode korelasional. Subjek penelitian 17 atlet. Hasil: (1) Indeks massa tubuh atlet 76,47\%. (2) indeks massa tubuh dan kecepatan $(0,418)$. (3) indeks massa tubuh dan kekuatan otot perut $(0,075)$. (3) indeks massa tubuh dan kelincahan $(0,493)$. (4) indeks massa tubuh dan daya tahan $(0,289)$. (5) antara indeks massa tubuh dan daya ledak $(0,438)$. Simpulan: (1) indeks massa tubuh atlet dalam kondisi baik, (2) hubungan yang signifikan hanya pada indeks massa tubuh dengan kelincahan, yang lain tidak signifikan.
\end{abstract}

Kata kunci: indeks massa tubuh, kondisi fisik, atlet sepakbola

\section{PENDAHULUAN}

Indeks massa tubuh dengan kondisi fisik pada tim sepakbola perlu lebih diperhatikan. Karena hal tersebut penting buat kemajuan sepakbola. Hal tersebut perlu diperhatikan karena masih kurangnya kondisi fisik dan indeks massa tubuh atlet, meskipun hanya beberapa atlet yang kurang baik. Terbukti dalam penelitian sebelumnya yang dilakukan oleh Deni setiawan bahwa kondisi fisik pemain sepakbola klub Asyabab di kabupaten Sidoarjo termasuk dalam kondisi sedang dengan jumlah subyek 20 pemain(Setiawan,2007.). status gizi juga terbukti dari peneltian terdahulu yang dilalukan oleh Ogen Gunawan terhadap pemain futsal Geral FC kota Makassar bahwa status gizi pemain dalam kondisi baik. Dalam penelitian tersebut mengambil 20 sampel pemain (Gunawan, 2019). Dan didukung oleh fakta bahwa indeks massa tubuh dan kondisi fisik 
atlet masih kurang karena kurangnya sosialisasi tentang penting asupan gizi terhadap atlet dan juga kurangnya latihan fisik terhadap atlet tersebut.

Kondisi fisik pada umumnya dipengaruhi oleh beberapa faktor seperti faktor 1) keturunan, 2) kematangan, kematangan yaitu semakin matang kondisi atlet makin bagus juga kondisi fisiknya, 3) gizi, gizi sangat penting bagi perkembangan atlet, 4) waktu istirahat dan tidur, 5) kebugaran, 6) lingkungan, dapat berupa lingkungan fisik dan lingkungan psikis, 7) motivasi yang tinggi juga dapat meningkatkan kemampuan atlet (Lloyd \& Oliver, 2012; Naser, Ali, \& Macadam, 2017).

Status gizi dalam hal ini menggunakan pengukuran IMT (Indeks Massa Tubuh) dibedakan menjadi berat badan kurang, berat badan ideal, berat badan lebih, gemuk dan sangat gemuk. Status gizi juga dipengaruhi oleh beberapa faktor seperti Pendapatan ekonomi atau kemampuan ekonomi untuk membeli makanan yang bergizi, sosial budaya yakni pandangan masyarakat yang salah terhadap makanan bergizi, pengaruh lingkungan budaya daerah seperti orang tinggal di daerah pantai akan banyak makan ikan, kesukaan terhadap makanan tertentu, kebersihan lingkunngan, fasilitas layanan kesehatan(Kalantar-Zadeh \& Fouque, 2017; Leslie \& Hankey, 2015).

\section{Sepakbola}

Sepakbola adalah olahraga menggunakan bola yang dimainkan oleh dua tim yang masing-masing beranggotakan 11 (sebelas) orang dan satu penjaga gawang. Sepakbola merupakan olahraga dimana sebuah tim berusaha untuk mencetak gol. Sepakbola bertujuan untuk mencetak gol sebanyak-banyaknya dengan menggunakan bola kulit ke gawang lawan. Sepakbola dimainkan di lapangan yang berbentuk persegi panjang dengan ukuran lapangan panjang 100-120 meter dan lebar 55-65 meter (Verburgh, Scherder, Van Lange, \& Oosterlaan, 2014).

\section{Status Gizi}

Status gizi adalah suatu keadaan yang diakibatkan oleh keseimbangan antara asupan zat gizi dari makanan dan kebutuhan zat gizi oleh tubuh (Volkert et al., 2015). Status gizi adalah ekspresi dari keadaan seimbang dalam bentuk variabel tertentu atau perwujudan dari nutriture dalam bentuk variabel tertentu (Ikizler, 2013). Status gizi adalah keadaan tubuh sebagai akibat konsumsi makanan dan penggunaan zat-zat gizi. Status gizi sangat berpengaruh terhadap pertumbuhan tubuh. Status gizi dibedakan menjadi gizi buruk, gizi kurang, gizi baik, dan gizi lebih (Shuhada et al., 2017). Status gizi adalah suatu kondisi tubuh sebagai hasil akhir dari keseimbangan antara makanan (zat gizi) yang masuk dalam tubuh dan kebutuhan akan zat gizi tersebut (Carvalhais et al., 2013; Kaner et al., 2015; Pandey, Mahendra Dev, \& Jayachandran, 2016). Status gizi merupakan ekspresi dari keadaan keseimbangan dalam bentuk variabel tertentu, atau perwujudan dari nutriture dalam bentuk variabel tertentu (Ghosh et al., 2014).

\section{Indeks Massa Tubuh}

Indeks massa tubuh adalah menilai status gizi dengan menggunakan perbandingan antara IMT/U atau BB/PB dengan median menurut umur, berat badan, panjang badan. Pengukuran ini mempunyai kelebihan yaitu dapat mengetahui gambaran resiko kegemukan anak (Twig et al., 2016).

\section{Kondisi Fisik}

Kondisi fisik adalah suatu kualitas fisik, kualitas psikis dan kemampuan fungsional peralatan tubuh individu. Kondisi fisik juga merupakan suatu hal penting untuk olahraga prestasi karena kondisi fisik sangat menentukan kualitas dan kemampuan untuk tuntutan pretasi yang optimal (Voss et al., 2016). Kondisi fisik adalah keadaan kemampuan jasmani yang dapat menyesuaikan fungsi alat-alat tubuhnya terhadap tugas jasmani. Kondisi fisik yang baik akan menunjang kemampuan taktik dan teknik atlet saat latihan maupun pertandingan (Griwijoyo, 2013:21).Kondisi fisik adalah salah satu syarat yang diperlukan dalam setiap usaha peningkatan prestasi atlet, bahkan dapat dikatakan bahwa kondisi fisik merupakan landasan dasar atau suatu awalan bagi olahragawan untuk berprestasi (Sajato, 1998:57).

\section{Kekuatan}

Kekuatan adalah kemampuan otot atau sekelompok otot untuk melakukan satu kali kontraksi secara maksimal melawan tahanan atau beban. Kekuatan otot sangat penting bagi setiap orang ataupun atlet. Kekuatan otot ini untuk memperkuat atlet dalam melakukan gerak pada olahraga apapun seperti sepakbola (Rodriguez- 
Ayllon et al., 2018). Kekuatan adalah kemampuan otot untuk melakukan kontraksi guna membangkitkan tegangan terhadap suatu tahanan (Mora-Gonzalez et al., 2019).

\section{kecepatan}

Kecepatan adalah kemampuan berpindah dari satu tempat ke tempat yang lain dalam waktu yang sesingkat singkatnya. Kecepatan bersifat lokomotor dan gerakannya bersifat siklik (satu jenis gerak yang dilakukan berulang-ulang seperti lari dan sebagainya) atau kecepatan gerak bagian tubuh seperti melakukan pukulan. Dalam hal ini kecepatan sangat penting untuk tetap menjaga mobilitas bagi setiap orang atau atlet (EstebanCornejo et al., 2017).

\section{Kelincahan}

Kelincahan adalah kemampuan mengubah arah atau posisi tubuh dengan cepat yang dilakukan bersamasama dengan gerakan lainnya. Kelincahan dibutuhkan untuk gerakan-gerakan yang cepat dan juga tetap seimbang atau tidak jatuh dari tumpuan (Villa-González, Ruiz, \& Chillón, 2015). Kelincahan adalah kemampuan seseorang untuk dapat mengubah arah dengan cepat dan tepat pada waktu bergerak tanpa kehilangan keseimbangan (Khan \& Hillman, 2014).

\section{Daya tahan}

Daya tahan jantung dan paru-paru adalah kesanggupan sistem jantung, paru-paru dan pembuluh darah untuk berfungsi secara optimal saat melakukan aktivitas sehari-hari, dalam waktu cukup lama tanpa mengalami kelelahan yang berarti. Daya tahan ini juga sangat penting untuk menunjang kerja otot dengan mengambil oksigen dan mengeluarkan ke otot yang aktif. Daya tahan yang kuat juga akan menjaga permainan atlet agar tetap dalam kondisi fisik yang baik (Milanović, Sporiš, \& Weston, 2015).

\section{Daya Ledak}

Daya ledak adalah gabungan antara kecepatan dan kekuatan atau pengarahan gaya otot maksimum dengan kecepatan maksimum. kemampuan yang cepat dan kuat juga dibutuhkan atlet untuk melakukan gerakangerakan yang cepat dan perlu tenaga kuat (Mora-Gonzalez et al., 2019).

Berdasarkan latar belakang yang telah dikemukakan di depan, indeks massa tubuh dan kondisi fisik dikaji lebih lanjut dan perlu dilakukan penelitian. Sehingga peneliti melakukan pemangamatan dan memilih Akademi Arema Ngunut Tulungagung. Dengan demikian, penulis akan melakukan penelitian yang berjudul "Studi Tentang indeks massa tubuh Terhadap Kondisi Fisik Atlet Sepakbola Akademi Arema Ngunut Tulungagung”.

\section{METODE}

Penelitian ini merupakan penelitian deskriptif kuantitatif dengan metode korelasional. Penelitian ini berusaha untuk membuktikan hubungan antara indeks massa tubuh $(X)$ dengan kondisi fisik $(Y)$. subjek penelitian yaitu 17 atlet sepakbola Akademi Arema Ngunut Tulungagung. Tempat yang digunakan dalam penelitian ini yaitu lapangan desa Sumberjo Desa Ngunut Tulungagung. Waktu pelaksanaan penelitian ini yaitu pada tanggal 24 Oktober 2019. Penelitian ini menggunakan dua jenis instrumen, yakni instrumen tes dan pengukuran, Instrumen variabel terikat berupa kondisi fisik $(\mathrm{Y})$ menggunakan tes kondisi fisik, instrumen variabel bebas berupa indeks massa tubuh $(X)$ dengan menggunakan Indeks Masa Tubuh menurut Umur (IMT)

Analisis data yang digunakan adalah analisis korelasional. Peneliti melakukan analisis korelasi product moment dari Pearson untuk mencari hubungan antar variabel yakni dengan mengkorelasikan variabel $\mathrm{X}$ dengan $Y$. 
HASIL

Hasil Pengukurang Indeks Massa Tubuh

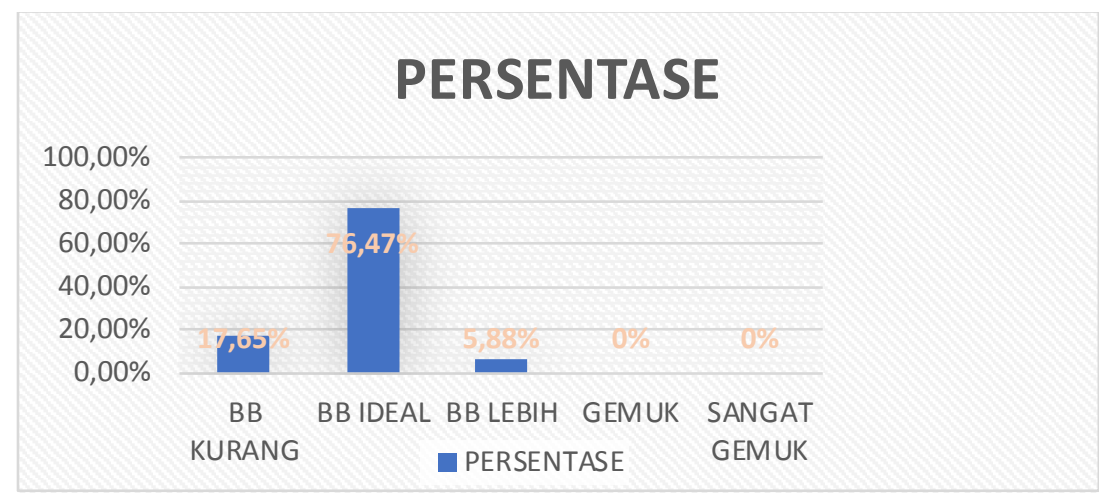

Gambar 1. Hasil Pengukuran Status Gizi Menggunakan IMT

Hasil Tes Kecepatan

Hasil Tes Kecepatan

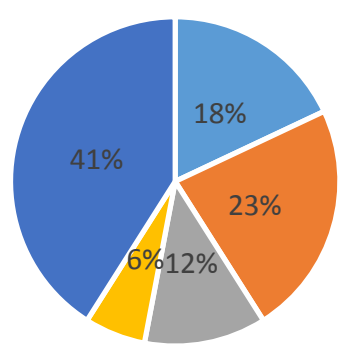

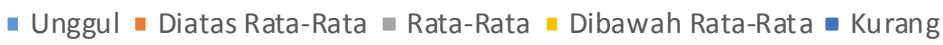

Gambar 2. Hasil Tes Kecepatan

Hasil Tes kekuatan Otot Perut

Hasil Tes Kekuatan Otot Perut

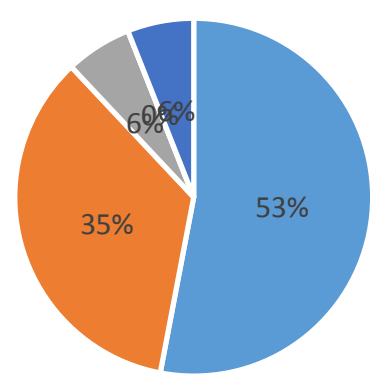

- Sangat Baik - Baik - Cukup - Kurang - Sangat Kurang

Gambar 3. Hasil Tes Kekuatan Otot Perut 


\section{Hasil Tes Kelincahan}

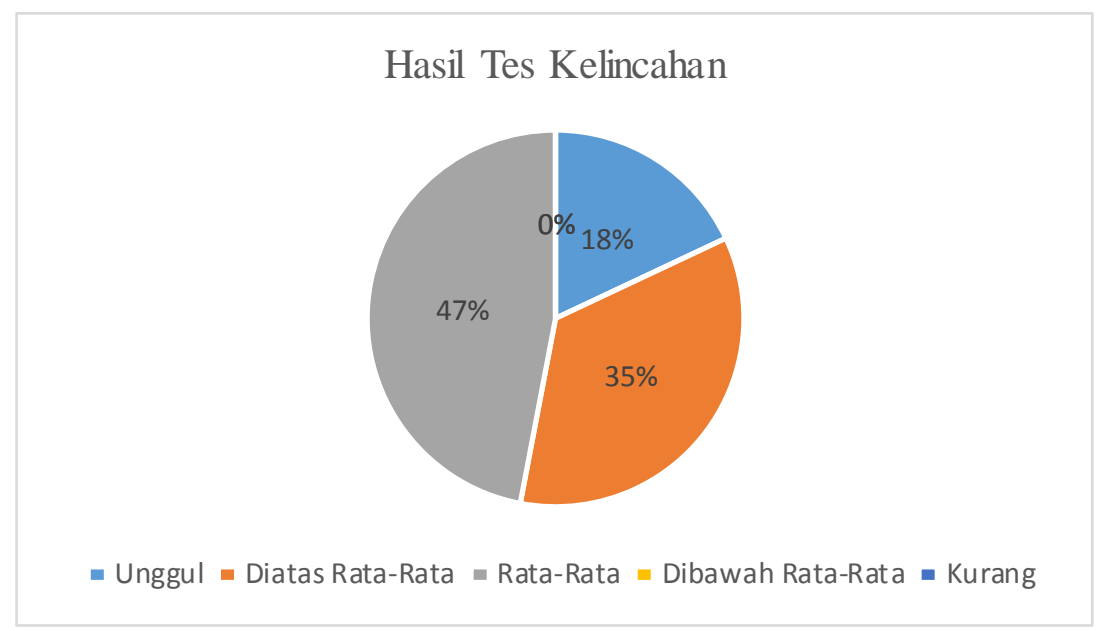

Gambar 4. Hasil Tes Kelincahan

\section{Hasil Tes Daya Tahan}

Hasil Tes Daya Tahan

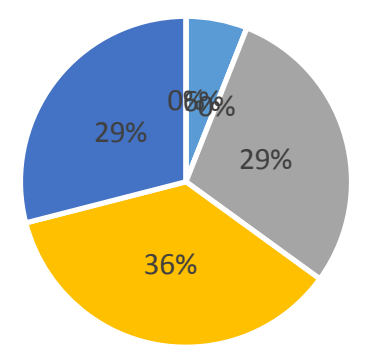

$$
\begin{aligned}
& \text { - Jelek } \quad \text { Dibawah Rata-Rata } \text { = Rata-Rata } \\
& \text { - Diatas Rata-Rata - Baik } \quad \text { Sangat Baik }
\end{aligned}
$$

Gambar 5. Hasil Tes Daya Tahan

Hasil Tes Daya Tahan

Hasil Tes Daya Ledak Otot Tungkai

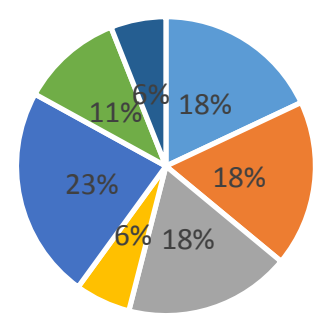

$$
\begin{array}{ll}
\text { - Sempurna } & \text { - Sangat Baik } \\
\text { - Rata-Rata } & \text { - Dibawah Rata-Rata }=\text { Kurang } \\
\text { - Kurang Sekali } &
\end{array}
$$

\section{Gambar 6. Hasil Tes Daya Ledak}

Uji Hipotesis

Penghitungan korelasi sederhana antara variabel status gizi $(X)$ dengan kondisi fisik $(Y)$ disajikan dalam tabel berikut: 
Tabel 1. Penyajian Koefisien Korelasi Antara Variabel Bebas Indeks Massa Tubuh (X) Kondisi Fisik (Y)

\begin{tabular}{|c|c|c|c|c|}
\hline \multirow{6}{*}{$\begin{array}{l}\text { Indek Massa } \\
\text { Tubuh }\end{array}$} & $\begin{array}{c}\text { Komponen } \\
\text { Kondisi Fisik }\end{array}$ & $\begin{array}{c}\text { Taraf } \\
\text { Signifikansi }\end{array}$ & $\begin{array}{c}\text { Hasil } \\
\text { Signifikansi } \\
\end{array}$ & keterangan \\
\hline & kecepatan & rhitung lebih dari & $\begin{array}{l}0,418 \text { kurang } \\
\text { dari } 0,482\end{array}$ & $\begin{array}{l}\text { Tidak } \\
\text { Signifikan }\end{array}$ \\
\hline & $\begin{array}{l}\text { Kekuatan otot } \\
\text { perut }\end{array}$ & $\begin{array}{l}\text { rtabel } \\
\text { rtabel }=0,482\end{array}$ & $\begin{array}{l}0,075 \text { kurang } \\
\text { dari } 0,482\end{array}$ & $\begin{array}{l}\text { Tidak } \\
\text { Signifikan }\end{array}$ \\
\hline & kelincahan & & $\begin{array}{l}0,493 \text { lebih dari } \\
0,482\end{array}$ & Signifikan \\
\hline & Daya Tahan & & $\begin{array}{l}0,289 \text { kurang } \\
\text { dari } 0,482\end{array}$ & $\begin{array}{l}\text { Tidak } \\
\text { signifikan }\end{array}$ \\
\hline & Daya Ledak & & $\begin{array}{l}0,438 \text { kurang } \\
\text { dari } 0,482\end{array}$ & $\begin{array}{l}\text { Tidak } \\
\text { Signifikan }\end{array}$ \\
\hline
\end{tabular}

Kriteria penerimaan atau penolakan hipotesis pada koefisien korelasi dengan $\alpha=0,05$ adalah jika Rhitung lebih dari Rtabel maka terdapat hubungan yang signifikan $\left(\mathrm{H}_{0}\right)$ ditolak dan $\left(\mathrm{H}_{\mathrm{a}}\right)$ diterima, jika $\leq$ Rtabel maka tidak terdapat hubungan yang signifikan $\left(\mathrm{Ha}_{\mathrm{a}}\right)$ ditolak dan $\left(\mathrm{H}_{0}\right)$ diterima.

\section{PEMBAHASAN}

\section{Hubungan Indeks Massa Tubuh Dengan Kecepatan}

Berdasarkan hasil penelitian pengukuran tersebut yang telah dilakukan terhadap 17 atlet diperoleh hasil yaitu sebanyak 3 atlet atau 17,65\% termasuk dalam kategori berat badan kurang, 13 atlet atau $76,47 \%$ termasuk dalam kategori berat badan ideal, 1 atlet atau 5,88\% termasuk dalam kategori berat badan lebih, dan tidak ada atlet yang termasuk dalam kategori gemuk maupun gemuk sekali. Jadi dapat disimpulkan bahwa hasil pengukuran status gizi pada 17 atlet sepakbola Akademi Arema Ngunut Tulungagung tergolong baik karena 13 dari 17 atlet atau 76,47\% termasuk berat badan ideal atau status gizi dalam kategori baik.

Berdasarkan hasil tes kecepatan yang diperoleh dari 17 atlet sepakbola Akademi Arema Ngunut Tulungagung yaitu sebanyak 3 atlet atau 17,65\% termasuk dalam kategori unggul, 4 atlet atau 23,53\% termasuk dalam kategori di atas rata-rata, 2 atlet atau 11,76\% termasuk dalam kategori rata-rata, 1 atlet atau $5,88 \%$ atlet termasuk dalam kategori di bawah rata-rata dan 7 atlet atau $41,18 \%$ yang termasuk dalam kategori kurang.

Berdasarkan hasil analisis korelasi antara indeks massa tubuh terhadap kecepatan yang dilakukan penghitungan korelasi menggunakan rumus korelasi product moment dari Pearson dan diperoleh korelasi sebesar 0,418. Kemudian untuk menguji signifikansi korelasi product moment dari Pearson menggunakan uji rhitung dibandingkan dengan rtabel. Lalu diperoleh rhitung sebesar 0,418 dengan signifikansi a=0,05 dan rtabel 0,482. Dapat disimpulkan bahwa dari perhitungan di atas tidak terdapat hubungan yang signifikan karena apabila rhitung kurang dari rtabel tidak terdapat hubungan yang signifikan. Sebaliknya jika rhitung lebih dari rtabel maka terdapat hubungan yang signifikan.

Selain itu dari penghitungan sumbangan efektif dan sumbangan relatif variabel bebas Indeks Massa Tubuh hanya menyumbang sebesar $17,5 \%$ terhadap variabel terikat kecepatan sedangkan sisanya $82,5 \%$ dipengaruhi oleh variabel lain. Dari tabel di atas diperoleh hasil sumbangan efektif yang diberikan sebesar $17,5 \%=R$ square. Sedangkan sumbangan relatif yang diberikan $100 \%$.

Berdasarkan teori yang dikemukakan oleh Bohlen, Boll, Schwarzer, \& Groneberg (2015) menyatakan bahwa indeks massa tubuh merupakan faktor yang mempengaruhi kondisi fisik ataupun mempengaruhi kecepatan atlet. Karena indeks massa tubuh yang ideal tentu akan mempermudah gerak atau mempermudah atlet untuk berlari ataupun bergerak lebih cepat.

Teori tersebut bertolak belakang dengan hasil penelitian ini karena dari hasil analisis data menunjukkan bahwa tidak ada hubungan yang signifikan antara indeks massa tubuh dengan kecepatan. Dari penelitian ini juga menunjukkan bahwa indeks massa tubuh hanya menyumbang sebesar $17,5 \%$ terhadap kecepatan.

Temuan peneliti sejalan dengan penelitian terdahulu yang menyatakan bahwa tidak ada hubungan yang 
signifikan antara indeks massa tubuh dengan kecepatan. Dalam penelitian yang dilakukan oleh Siregar \& Sitompul (2019) tersebut menunjukkan bahwa Dari 20 sampel yang telah diteliti menunjukkan bahwa seluruh atlet yang telah diteliti indeks massa tubuh berkategori normal dengan nilai indeks massa tubuh paling rendah adalah $18,21 \%$ dan paling tinggi adalah $25,61 \%$ dengan rata-rata $21,37 \%$ dan hasil tes kecepatan lari sprint 30 meter atlet SBB tunas muda medan kategori terbanyak adalah kurang dengan jumlah (13 orang) kategori cukup (4 orang) kategori baik (3 orang). Dengan hasil korelasional antara Indeks massa tubuh dengan kecepatan yaitu 0,21 dengan taraf signifikansi (lebih dari 0,05 ).

\section{Hubungan Indeks Massa Tubuh Dengan Kekuatan Otot Perut}

Berdasarkan hasil penelitian pengukuran tersebut yang telah dilakukan terhadap 17 atlet diperoleh hasil yaitu sebanyak 3 atlet atau 17,65\% termasuk dalam kategori berat badan kurang, 13 atlet atau 76,47\% termasuk dalam kategori berat badan ideal, 1 atlet atau 5,88\% termasuk dalam kategori berat badan lebih, dan tidak ada atlet yang termasuk dalam kategori gemuk maupun gemuk sekali. Jadi dapat disimpulkan bahwa hasil pengukuran status gizi pada 17 atlet sepakbola Akademi Arema Ngunut Tulungagung tergolong baik karena 13 dari 17 atlet atau 76,47\% termasuk berat badan ideal atau status gizi dalam kategori baik.

Berdasarkan hasil tes kekuatan otot perut yang diperoleh dari 17 atlet sepakbola Akademi Arema Ngunut Tulungagung yaitu sebanyak 9 atlet atau 53\% termasuk dalam kategori sangat baik, 6 atlet atau 35\% termasuk dalam kategori baik, 1 atlet atau $6 \%$ termasuk dalam kategori cukup, 0 atlet atau $0 \%$ atlet termasuk dalam kategori kurang dan 1 atlet atau $6 \%$ yang termasuk dalam kategori sangat kurang.

Berdasarkan hasil analisis korelasi antara indeks massa tubuh terhadap kekuatan otot perut yang dilakukan penghitungan korelasi menggunakan rumus korelasi product moment dari Pearson dan diperoleh korelasi sebesar 0,075. Kemudian untuk menguji signifikansi korelasi product moment dari Pearson menggunakan uji rhitung dibandingkan dengan rtabel. Lalu diperoleh rhitung sebesar 0,075 dengan signifikansi $a=0,05$ dan rtabel 0,482. Dapat disimpulkan bahwa dari perhitungan di atas tidak terdapat hubungan yang signifikan karena apabila rhitung kurang dari rtabel tidak terdapat hubungan yang signifikan. Sebaliknya jika rhitung lebih dari rabel maka terdapat hubungan yang signifikan.

Selain itu dari penghitungan sumbangan efektif dan sumbangan relatif variabel bebas Indeks Massa Tubuh hanya menyumbang sebesar $0,6 \%$ terhadap variabel terikat kekuatan otot perut sedangkan sisanya $99,4 \%$ dipengaruhi oleh variabel lain. Dari tabel di atas diperoleh hasil sumbangan efektif yang diberikan sebesar $0,6 \%=R$ square. Sedangkan sumbangan relatif yang diberikan $100 \%$.

Berdasarkan teori yang dikemukakan oleh Arends et al., (2017) bahwa nutrisi atau gizi belum tentu dapat meningkatkan kapasitas kekuatan otot, kapasitas maksimal otot maupun power pada tubuh ses eorang. Teori ini sejalan dengan penelitian ini yang menunjukkan bahwa tidak ada hubungan yang signifikan antara indeks massa tubuh dengan kekuatan otot perut. Karena dalam penelitian ini indeks massa tubuh hanya menyumbang sedikit terhadap daya tahan dengan persentase $0,6 \%$ dan sisanya dipengaruhi oleh faktor lain.

Hasil penelitian ini juga sejalan dengan peneltian terdahulu yang menyatakan tidak ada hubungan yang signifikan antara indeks massa tubuh dengan kekuatan otot perut. Berdasarkan hasil penelitian terdahulu yang dilakukan oleh Siregar \& Sitompul (2019) tersebut bahwa Dari 20 sampel yang telah diteliti menunjukkan bahwa seluruh atlet yang telah diteliti indeks massa tubuh berkategori normal dengan nilai indeks massa tubuh paling rendah adalah $18,21 \%$ dan paling tinggi adalah $25,61 \%$ dengan rata-rata $21,37 \%$ dan dari hasil tes kekuatan otot atlet SSB Tunas Muda Medan, kategori terbanyak adalah cukup dengan jumlah (12 orang) kategori baik (4 orang) kategori baik sekali (3 orang). Dengan persentase rata-rata $36,2 \%$. Dengan hasil korelasional antara Indeks massa tubuh dengan kekuatan otot perut yaitu 0,07 dengan taraf signifikansi (lebih dari 0,05$)$.

\section{Hubungan Indeks Massa Tubuh Dengan Kelincahan}

Berdasarkan hasil penelitian pengukuran tersebut yang telah dilakukan terhadap 17 atlet diperoleh hasil yaitu sebanyak 3 atlet atau 17,65\% termasuk dalam kategori berat badan kurang, 13 atlet atau 76,47\% termasuk dalam kategori berat badan ideal, 1 atlet atau 5,88\% termasuk dalam kategori berat badan lebih, dan tidak ada atlet yang termasuk dalam kategori gemuk maupun gemuk sekali. Jadi dapat disimpulkan bahwa hasil pengukuran status gizi pada 17 atlet sepakbola Akademi Arema Ngunut Tulungagung tergolong baik karena 13 dari 17 atlet atau $76,47 \%$ termasuk berat badan ideal atau status gizi dalam kategori baik. 
Berdasarkan hasil tes kelincahan yang diperoleh dari 17 atlet sepakbola Akademi Arema Ngunut Tulungagung yaitu sebanyak 3 atlet atau 18\% termasuk dalam kategori unggul, 6 atlet atau 35\% termasuk dalam kategori di atas rata-rata, 8 atlet atau $47 \%$ termasuk dalam kategori rata-rata, 0 atlet atau $0 \%$ atlet termasuk dalam kategori di bawah rata-rata dan 0 atlet atau $0 \%$ yang termasuk dalam kategori kurang.

Berdasarkan hasil analisis korelasi antara indeks massa tubuh terhadap kelincah yang dilakukan penghitungan korelasi menggunakan rumus korelasi product moment dari Pearson dan diperoleh korelasi sebesar 0,493. Kemudian untuk menguji signifikansi korelasi product moment dari Pearson menggunakan uji rhitung dibandingkan dengan rtabel. Lalu diperoleh rhitung sebesar 0,493 dengan signifikansi $a=0,05$ dan rtabel 0,482. Dapat disimpulkan bahwa dari perhitungan di atas terdapat hubungan yang signifikan karena apabila rhitung lebih dari rtabel terdapat hubungan yang signifikan. Sebaliknya jika rhitung kurang dari rabel maka tidak terdapat hubungan yang signifikan.

Selain itu dari penghitungan sumbangan efektif dan sumbangan relatif variabel bebas Indeks Massa Tubuh hanya menyumbang sebesar $24,3 \%$ terhadap variabel terikat kelincahan sedangkan sisanya $75,7 \%$ dipengaruhi oleh variabel lain. Dari tabel di atas diperoleh hasil sumbangan efektif yang diberikan sebesar $24,3 \%=R$ square. Sedangkan sumbangan relatif yang diberikan $100 \%$.

Berdasar teori yang dikemukakan oleh Leppänen et al., (2017) tersebut bahwa kelincahan merupakan kemampuan seseorang dalam mengubah arah dengan cepat dan tepat pada waktu bergerak tanpa kehilangan keseimbangan. Tentu untuk memperoleh kelincahan yang indeks massa tubuh nya juga ada harus ideal untuk mempermudah gerakan supaya cepat dan tepat tanpa hilang keseimbangan. Teori tersebut sejalan dengan hasil penelitian ini bahwa ada hubungan yang signifikan antara indeks massa tubuh dengan kelincahan.

Temuan peneliti juga sejalan dengan hasil penelitian yang menunjukkan bahwa ada hubungan yang signifikan antara indeks massa tubuh dengan kelincahan. Penelitian terdahulu yang dilakukan oleh Prihatini Dkk (2019) terhadap 18 atlet pra porprov Mojokerto menunjukan ada hubungan indek massa tubuh dengan kelincahan yang menyatakan nilai koefisien korelasi positif sebesar $(0,629)$ yang menyatakan bahwa semakin tinggi nilai indek massa tubuh maka semakin tinggi pula nilai waktu kelincahan.

\section{Hubungan Indeks Massa Tubuh Dengan Daya Tahan}

Berdasarkan hasil penelitian pengukuran tersebut yang telah dilakukan terhadap 17 atlet diperoleh hasil yaitu sebanyak 3 atlet atau 17,65\% termasuk dalam kategori berat badan kurang, 13 atlet atau 76,47\% termasuk dalam kategori berat badan ideal, 1 atlet atau 5,88\% termasuk dalam kategori berat badan lebih, dan tidak ada atlet yang termasuk dalam kategori gemuk maupun gemuk sekali. Jadi dapat disimpulkan bahwa hasil pengukuran status gizi pada 17 atlet sepakbola Akademi Arema Ngunut Tulungagung tergolong baik karena 13 dari 17 atlet atau 76,47\% termasuk berat badan ideal atau status gizi dalam kategori baik.

Data diperoleh dari 17 atlet sepakbola Akademi Arema Ngunut Tulungagung yaitu sebanyak 1 atlet atau 6\% termasuk dalam kategori jelek, 0 atlet atau 0\% termasuk dalam kategori di bawah rata-rata, 5 atlet atau 29\% termasuk dalam kategori rata-rata, 6 atlet atau $36 \%$ atlet termasuk dalam kategori di atas rata-rata dan 6 atlet atau $36 \%$ yang termasuk dalam kategori baik. Dan 0 atlet atau $0 \%$ yang termasuk dalam kategori sangat baik.

Berdasarkan analisis korelasi antara indeks massa tubuh terhadap daya tahan yang dilakukan penghitungan korelasi menggunakan rumus korelasi product moment dari Pearson dan diperoleh korelasi sebesar 0,289. Kemudian untuk menguji signifikansi korelasi product moment dari Pearson menggunakan uji rhitung dibandingkan dengan rtabel. Lalu diperoleh rhitung sebesar 0,289 dengan signifikansi $a=0,05$ dan rabel 0,482. Dapat disimpulkan bahwa dari perhitungan di atas tidak terdapat hubungan yang signifikan karena apabila rhitung lebih dari rtabel terdapat hubungan yang signifikan. Sebaliknya jika rhitung kurang dari rabel maka tidak terdapat hubungan yang signifikan.

Selain itu dari penghitungan sumbangan efektif dan sumbangan relatif variabel bebas Indeks Massa Tubuh hanya menyumbang sebesar $8,3 \%$ terhadap variabel terikat daya tahan sedangkan sisanya $91,7 \%$ dipengaruhi oleh variabel lain. Dari tabel di atas diperoleh hasil sumbangan efektif yang diberikan sebesar $8,3 \%=R$ square. Sedangkan sumbangan relatif yang diberikan $100 \%$.

Berdasarkan teori yang dikemukakan oleh Kominiarek \& Rajan (2016) menunjukkan bahwa nutrisi atau gizi yang baik belum tentu membuat power ataupun kekuatan otot menjadi baik. Tetapi persediaan energi yang terbatas tentu akan menghambat atau dapat membatasi daya tahan. Teori tersebut bertolak belakang dengan 
hasil penelitian ini yang menunjukkan bahwa tidak ada hubungan yang signifikan antara indeks massa tubuh dengan daya tahan. Karena dalam penelitian ini indeks massa tubuh hanya menyumbang sedikit terhadap daya tahan dengan persentase $8,3 \%$ dan sisanya dipengaruhi oleh faktor lain.

Penelitian ini sejalan dengan penelitian yang terdahulu yang menunjukkan bahwa tidak ada hubungan yang signifikan antara indeks massa tubuh dengan daya tahan. Penelitian terdahulu yang dilakukan oleh Siregar \& Sitompul (2019) tersebut bahwa Dari 20 sampel yang telah diteliti menunjukkan bahwa seluruh atlet yang telah diteliti indeks massa tubuh berkategori normal dengan nilai indeks massa tubuh paling rendah adalah $18,21 \%$ dan paling tinggi adalah $25,61 \%$ dengan rata-rata $21,37 \%$ dan hasil tes daya tahan dari 20 atlet Atlet ssb tunas muda medan, kategori terbanyak adalah kurang sekali dengan jumlah (16 orang) kategori kurang (4 orang). Dengan persentase rata-rata $42,88 \%$. Dengan hasil korelasional antara Indeks massa tubuh dengan kekuatan otot perut yaitu 0,30 dengan taraf signifikansi (lebih dari 0,05).

\section{Hubungan Indeks Massa Tubuh Dengan Daya Ledak}

Berdasarkan hasil penelitian pengukuran tersebut yang telah dilakukan terhadap 17 atlet diperoleh hasil yaitu sebanyak 3 atlet atau 17,65\% termasuk dalam kategori berat badan kurang, 13 atlet atau 76,47\% termasuk dalam kategori berat badan ideal, 1 atlet atau 5,88\% termasuk dalam kategori berat badan lebih, dan tidak ada atlet yang termasuk dalam kategori gemuk maupun gemuk sekali. Jadi dapat disimpulkan bahwa hasil pengukuran status gizi pada 17 atlet sepakbola Akademi Arema Ngunut Tulungagung tergolong baik karena 13 dari 17 atlet atau 76,47\% termasuk berat badan ideal atau status gizi dalam kategori baik.

Berdasarkan tes daya ledak dari 17 atlet sepakbola Akademi Arema Ngunut Tulungagung yaitu sebanyak 3 atlet atau $18 \%$ termasuk dalam kategori sempurna, 3 atlet atau $18 \%$ termasuk dalam kategori sangat baik, 3 atlet atau $18 \%$ termasuk dalam kategori di atas rata-rata, 1 atlet atau $6 \%$ atlet termasuk dalam kategori ratarata, 4 atlet atau $23 \%$ yang termasuk dalam kategori di bawah rata-rata, 2 atlet atau $11 \%$ termasuk dalam kategori kurang, dan 1 atlet atau 6\% termasuk dalam kategori kurang sekali.

Berdasarkan hasil analisis korelasi antara indeks massa tubuh terhadap daya ledak yang dilakukan penghitungan korelasi menggunakan rumus korelasi product moment dari Pearson dan diperoleh korelasi sebesar 0,438. Kemudian untuk menguji signifikansi korelasi product moment dari Pearson menggunakan uji rhitung dibandingkan dengan rtabel. Lalu diperoleh rhitung sebesar 0,438 dengan signifikansi $a=0,05$ dan rtabel 0,482. Dapat disimpulkan bahwa dari perhitungan di atas terdapat hubungan yang signifikan karena apabila rhitung lebih dari rtabel terdapat hubungan yang signifikan. Sebaliknya jika rhitung kurang dari rtabel maka tidak terdapat hubungan yang signifikan.

Selain itu dari penghitungan sumbangan efektif dan sumbangan relatif variabel bebas Indeks Massa Tubuh hanya menyumbang sebesar $19,2 \%$ terhadap variabel terikat daya ledak sedangkan sisanya $71,8 \%$ dipengaruhi oleh variabel lain. Dari tabel di atas diperoleh hasil sumbangan efektif yang diberikan sebesar $19,2 \%=R$ square. Sedangkan sumbangan relatif yang diberikan $100 \%$.

Berdasarkan teori yang dikemukakan oleh para ahli bahwa daya ledak merupakan kemampuan untuk mengerahkan kekuatan maksimal dalam waktu yang cepat. Tentu dalam melalukan daya ledak membutuhkan indeks massa tubuh yang bagus supaya gerakan yang cepat dan maksimal dapat dilakukan (Behm et al., 2017; Hartmann et al., 2015; Suchomel, Nimphius, Bellon, \& Stone, 2018). Teori ini berbanding terbalik dengan penelitian ini yang menunjukkan tidak ada hubungan antara indeks massa tubuh dengan daya ledak. Karena dalam penelitian ini indeks massa tubuh hanya menyumbang sedikit terhadap daya ledak dengan persentase $19,2 \%$ dan sisanya dipengaruhi oleh faktor lain.

penelitian ini sejalan dengan penelitian terdahulu yang dilakukan oleh Siregar \& Sitompul (2019) yang menunjukkan bahwa Dari 20 sampel yang telah diteliti menunjukkan bahwa seluruh atlet yang telah diteliti indeks massa tubuh berkategori normal dengan nilai indeks massa tubuh paling rendah adalah $18,21 \%$ dan paling tinggi adalah $25,61 \%$ dengan rata-rata $21,37 \%$ dan hasil tes daya ledak Atlet SSB Tunas Muda medan, kategori terbanyak adalah kurang dengan jumlah (15orang) kategori kurang (5 orang). Dengan presentase rata-rata $125,1 \%$. Dengan hasil korelasional antara Indeks massa tubuh dengan kekuatan otot perut yaitu 0,34 dengan taraf signifikansi (lebih dari 0,05). 


\section{KESIMPULAN}

Hasil dari penelitian yang telah dilakukan terhadap atlet Akademi Arema Ngunut Tulungagung menunjukkan bahwa indeks massa tubuh atlet sepakbola Akademi Arema Ngunut tulungagung tergolong ideal. Tidak terdapat hubungan yang signifikan antara indeks massa tubuh dan kecepatan. Tidak terdapat hubungan yang signifikan antara indeks massa tubuh dan kekuatan otot perut. Terdapat hubungan yang signifikan antara indeks massa tubuh dan kelincahan. Tidak terdapat hubungan yang signifikan antara indeks massa tubuh dan daya tahan. Tidak terdapat hubungan yang signifikan antara indeks massa tubuh dan daya ledak.

\section{Ucapan Terima Kasih}

Peneliti menyadari, bahwa dalam penulisan artikel ini tidak akan selesai tanpa bantuan dari berbagai pihak. Sehingga dikesempatan yang baik ini peneliti mengucapkan terimakasih yang sebesar-besarya kepada Dr. Sapto Adi, M.Kes., selaku Dekan Fakultas IImu Keolahragaan Universitas Negeri Malang, yang telah memberikan kesempatan bagi peneliti untuk menyelesaikan pendidikan dan menempuh jenjang sarjana di FIK UM, Dr. dr. Moch. Yunus, M.Kes., sebagai Wakil Dekan I Fakultas IImu Keolahragaan yang telah membantu dan memberikan izin dalam proses penelitian, Dr. Lokananta Teguh Hari Wiguno, M.Kes., selaku Ketua Jurusan Pendidikan Jasmani dan Kesehatan Fakultas IImu Keolahragaan, Dr. Eko Hariyanto, M.Pd., selaku Dosen Pembimbing I yang telah meluangkan waktu memberikan bimbingan, memberikan motivasi, masukan, dan saran-saran yang sangat berharga bagi peneliti, Bapak Eko selaku pelatih, Pak Agung selaku Ketua Tim Akademi Arema Ngunut Tulungagung. Beserta anggota tim Akademi Arema Ngunut Tulungagung yang telah menerima dan memberikan izin bagi peneliti untuk melaksanakan penelitian, dan atlet yang bersedia menjadi sampel penelitian.

\section{DAFTAR PUSTAKA}

Arends, J., Bachmann, P., Baracos, V., Barthelemy, N., Bertz, H., Bozzetti, F., ... Preiser, J. C. (2017). ESPEN guidelines on nutrition in cancer patients. Clinical Nutrition. https://doi.org/10.1016/j.clnu.2016.07.015

Behm, D. G., Young, J. D., Whitten, J. H. D., Reid, J. C., Quigley, P. J., Low, J., ... Granacher, U. (2017). Effectiveness of traditional strength vs. power training on muscle strength, power and speed with youth: A systematic review and meta-analysis. Frontiers in Physiology. https://doi.org/10.3389/fphys.2017.00423

Bohlen, A., Boll, M., Schwarzer, M., \& Groneberg, D. A. (2015). Body-Mass-Index. Diabetologe. https://doi.org/10.1007/s11428-015-1388-8

Carvalhais, L. C., Dennis, P. G., Fan, B., Fedoseyenko, D., Kierul, K., Becker, A., ... Borriss, R. (2013). Linking Plant Nutritional Status to Plant-Microbe Interactions. PLOS ONE. https://doi.org/10.1371/journal.pone.0068555

Esteban-Cornejo, I., Cadenas-Sanchez, C., Contreras-Rodriguez, O., Verdejo-Roman, J., Mora-Gonzalez, J., Migueles, J. H., ... Ortega, F. B. (2017). A whole brain volumetric approach in overweight/obese children: Examining the association with different physical fitness components and academic performance. The ActiveBrains project. Neurolmage. https://doi.org/10.1016/j.neuroimage.2017.08.011

Ghosh, T. S., Gupta, S. Sen, Bhattacharya, T., Yadav, D., Barik, A., Chowdhury, A., ... Nair, G. B. (2014). Gut microbiomes of Indian children of varying nutritional status. PLOS ONE. https://doi.org/10.1371/journal.pone.0095547

Griwijoyo, S. (2013). IImu Faal Olahraga. Bandung: PT Remaja Rosdakarya.

Gunawan, O. (2019). Survei Status Gizi, Daya Tahan Kardiovaskuler dan Keterampilan Bermain Futsal Pada Club Geral FC Makassar.

Hartmann, H., Wirth, K., Keiner, M., Mickel, C., Sander, A., \& Szilvas, E. (2015). Short-term Periodization Models: Effects on Strength and Speed-strength Performance. Sports Medicine. https://doi.org/10.1007/s40279-015-0355-2 
Ikizler, T. A. (2013). A patient with CKD and poor nutritional status. Clinical Journal of the American Society of Nephrology. https://doi.org/10.2215/CJN.04630513

Kalantar-Zadeh, K., \& Fouque, D. (2017). Nutritional Management of Chronic Kidney Disease. New England Journal of Medicine. https://doi.org/10.1056/nejmra1700312

Kaner, G., Soylu, M., Yüksel, N., Inanç, N., Ongan, D., \& Başmisirli, E. (2015). Evaluation of nutritional status of patients with depression. BioMed Research International. https://doi.org/10.1155/2015/521481

Khan, N. A., \& Hillman, C. H. (2014). The relation of childhood physical activity and aerobic fitness to brain function and cognition: A review. Pediatric Exercise Science. https://doi.org/10.1123/pes.2013-0125

Kominiarek, M. A., \& Rajan, P. (2016). Nutrition Recommendations in Pregnancy and Lactation. Medical Clinics of North America. https://doi.org/10.1016/j.mcna.2016.06.004

Leppänen, M. H., Henriksson, P., Delisle Nyström, C., Henriksson, H., Ortega, F. B., Pomeroy, J., ... Löf, M. (2017). Longitudinal physical activity, body composition, and physical fitness in preschoolers. Medicine and Science in Sports and Exercise. https://doi.org/10.1249/MSS.0000000000001313

Leslie, W., \& Hankey, C. (2015). Aging, Nutritional Status and Health. Healthcare. https://doi.org/10.3390/healthcare3030648

Lloyd, R. S., \& Oliver, J. L. (2012). The youth physical development model: A new approach to long-term athletic development. Strength and Conditioning Journal. https://doi.org/10.1519/SSC.0b013e31825760ea

Milanović, Z., Sporiš, G., \& Weston, M. (2015). Effectiveness of High-Intensity Interval Training (HIT) and Continuous Endurance Training for VO2max Improvements: A Systematic Review and Meta-Analysis of Controlled Trials. Sports Medicine. https://doi.org/10.1007/s40279-015-0365-0

Mora-Gonzalez, J., Esteban-Cornejo, I., Cadenas-Sanchez, C., Migueles, J. H., Molina-Garcia, P., RodriguezAyllon, M., ... Ortega, F. B. (2019). Physical Fitness, Physical Activity, and the Executive Function in Children with Overweight and Obesity. Journal of Pediatrics. https://doi.org/10.1016/j.jpeds.2018.12.028

Naser, N., Ali, A., \& Macadam, P. (2017). Physical and physiological demands of futsal. Journal of Exercise Science and Fitness. https://doi.org/10.1016/j.jesf.2017.09.001

Pandey, V. L., Mahendra Dev, S., \& Jayachandran, U. (2016). Impact of agricultural interventions on the nutritional status in South Asia: A review. Food Policy. https://doi.org/10.1016/j.foodpol.2016.05.002

Prihatini, D.A \& Achmad, W. (2019). Hubungan Antara Indeks Massa Tubuh Dengan Daya Tahan Kardiovaskuler Dan Kelincahan Pemain Sepakbola. 45-50.

Rodriguez-Ayllon, M., Cadenas-Sanchez, C., Esteban-Cornejo, I., Migueles, J. H., Mora-Gonzalez, J., Henriksson, P., ... Ortega, F. B. (2018). Physical fitness and psychological health in overweight/obese children: A cross-sectional study from the ActiveBrains project. Journal of Science and Medicine in Sport. https://doi.org/10.1016/j.jsams.2017.09.019

Sajato. (1998). Pembinaan Kondisi Fisik Dalam Olahraga. Jakarta: Departemen Pendidikan dan Kebudayaan Direktorat Jenderal Pendidikan Tinggi Proyek Pengadaan Buku Pada Lembaga Pengembangan Tenaga Pendidikan.

Setiawan, D. (n.d.). Kondisi Fisik Pemain Sepakbola Klub Asyabab DI Kabupaten Sidoarjo. 1-5.

Shuhada, N. A., Aziz, A., Mohd, N. I., Teng, F., Abdul, M. R., Hamid, \& Ismail, N. H. (2017). Assessing the nutritional status of hospitalized elderly. Clinical Interventions in Aging. https://doi.org/10.2147/CIA.S140859

Siregar, N. S., \& Sitompul, S. F. M. (2019). Hubungan Status Gizi Terhadap Kondisi Fisik Atlet SSB Tunas Muda. 3(1), 47-55.

Suchomel, T. J., Nimphius, S., Bellon, C. R., \& Stone, M. H. (2018). The Importance of Muscular Strength: Training Considerations. Sports Medicine. https://doi.org/10.1007/s40279-018-0862-z

Twig, G., Yaniv, G., Levine, H., Leiba, A., Goldberger, N., Derazne, E., ... Kark, J. D. (2016). Body-Mass Index 
in 2.3 Million Adolescents and Cardiovascular Death in Adulthood. New England Journal of Medicine. https://doi.org/10.1056/nejmoa1503840

Verburgh, L., Scherder, E. J. A., Van Lange, P. A. M., \& Oosterlaan, J. (2014). Executive functioning in highly talented soccer players. PLOS ONE. https://doi.org/10.1371/journal.pone.0091254

Villa-González, E., Ruiz, J. R., \& Chillón, P. (2015). Associations between active commuting to school and health-related physical fitness in spanish school-aged children: A cross-sectional study. International Journal of Environmental Research and Public Health. https://doi.org/10.3390/ijerph120910362

Volkert, D., Chourdakis, M., Faxen-Irving, G., Frühwald, T., Landi, F., Suominen, M. H., ... Schneider, S. M. (2015). ESPEN guidelines on nutrition in dementia. Clinical Nutrition. https://doi.org/10.1016/j.clnu.2015.09.004

Voss, M. W., Weng, T. B., Burzynska, A. Z., Wong, C. N., Cooke, G. E., Clark, R., ... Kramer, A. F. (2016). Fitness, but not physical activity, is related to functional integrity of brain networks associated with aging. Neurolmage. https://doi.org/10.1016/j.neuroimage.2015.10.044 